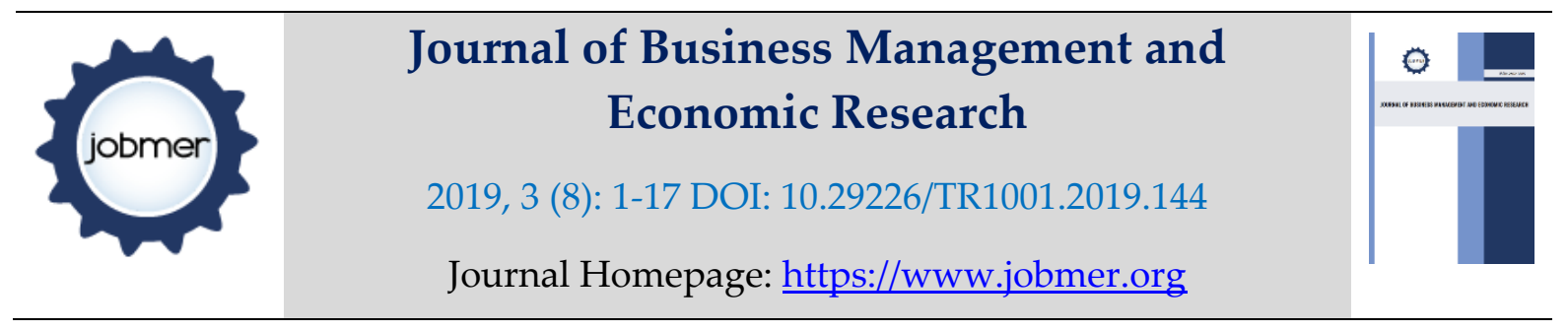

\title{
THE ROLE OF CUSTOMER TRUST AS A MEDIATION ON THE EFFECT OF CORPORATE IMAGES AND PRICE FAIRNESS TO CUSTOMER LOYALTY
}

\author{
A.A.Ayu Ratih Permata Sari \\ Magister Management Program of Faculty of Economic and Business Udayana University, \\ Bali, Indonesia \\ ratihpermata92@gmail.com
}

\section{Ni Nyoman Kerti Yasa}

Magister Management Program of Faculty of Economic and Business Udayana University, Bali, Indonesia

ninyomankertiy@gmail.com

\begin{abstract}
The purpose of this study is determine the role of customer trust in mediating the corporate image and the price fairness to customer loyalty mapemall.com. Testing the research hypothesis using Structural Equation Modeling (SEM) analysis techniques using SMARTPLS assistance, using IBM SPSS Statistics 22 to test validity and reliability, and the sample in this study amounted to 85 respondents, taken using pposive sampling technique, with the criteria of respondents namely customers who have been shopping online at Mapemall.com for the past year at least twice, living in the city of Denpasar. The results showed that (1) the corporate image had a positive and significant effect on customer trust, (2) the price fairness has a positive and significant effect on customer trust, (3) the corporate image has a positive and significant effect on customer loyalty, (4) the price fairness and significant to customer loyalty, (5) customer trust has a positive and significant effect on customer loyalty, (6) customer trust can mediate the relationship between corporate image and customer loyalty, and (7) customer trust can mediate the price fairness relationships with customer loyalty.
\end{abstract}

Keywords: corporate image, price fairness, customer trust, customer loyalty 


\section{Introduction}

Determinants of customer loyalty in online shop are effect by several variables including image and price (Leonnard et al, 2014). Abdel-Salam et al. (2010) define corporate image as a general impression left in the minds of customers as a result of a collection of feelings, ideas, attitudes, and experiences with companies that are stored in memory. The impression is then transformed into a positive or negative image according to the feelings and experiences of customers in the company.

Research by Widiyanto and Toro (2012) states that corporate image has a significant effect on customer trust. The results of the study of $\mathrm{Li}$ and Chaipoopirutana (2014) state that corporate image has a significant positive positive effect on customer loyalty. Kim and Lee (2010) state that corporate image is an important role in providing a positive effect in building and maintaining customer loyalty in the market.

In addition to corporate image, customer loyalty can also be effect by the price fairness. Price is one of the most flexible marketing mix elements that can quickly change, after changing certain product characteristics and services (Virvilaite et al., 2009). Price is the amount of money charged on a product, or the amount of value that customers exchange for benefits because they own and use the product, Kotler and Armstrong (2012: 439). Usually an individual will use price as a comparative information intensive to be able to assess a product from existing brands to make a purchase (Dimyati and Subagio, 2016).

A customer in purchasing a product will certainly be effect by several marketing stimuli (Yulihasri, et al., 2011). Products that have reasonable prices that the company provides to its customers are marketing stimuli in increasing the value of their customers, (Ananta Wijaya, 2017). Price fairness as an assessment of a result and process to achieve a reasonable and acceptable outcome (Consuegra et al., 2007). Haghighi et al. (2012) states that the perception of price fairness gives a significant positive effect on customer trust.

The results of this study contradict the results of a study conducted by Doong et al. (2008) which states that price fairness does not have a significant impact on loyalty (loyalty intention). This is supported by the results of the study of Leonnard et al. (2014), which states that prices do not have a significant effect on loyalty. Therefore the pricing decision is very important in determining how far a service is valued by a customer because in the process of forming the business image itself and determining its quality, Hassan et al. (2013).

The existence of differences in results from several previous studies, of course, can enable the role of trust in bridging between the corporate image and the price fairness of a customer's loyalty. As is known, trust 
trust is the belief that someone will find what he wants or is expected to generally have someone that words, promises, or statements of others can be trusted (Akbar and Parvez, 2009: 26). This was also supported by previous research which stated that the main determinant of customer loyalty in both online and offline markets was trust and satisfaction (Doong et al, 2008). This is in line with Costa and Chaipoopirutana (2014) research, which states that trust has a significant relationship and a moderating relationship to customer loyalty.

\section{Literature Review}

Company image is the result of a collection of processes in which consumers compare the various attributes possessed by the company. The attributes in question are for example products, prices, product quality, and service quality. Consumers will make subjective perceptions of the company and all its activities as expressed by Chiu and Hsu (2010). This perception will be different for each person even if faced with the same object. According to Subroto and Rahayu (2014) if companies want to increase customer loyalty, this can be done by increasing the trust and image of the company. Based on research conducted by Leonnard et al. (2014) states that corporate image has a significant positive effect on consumer loyalty.

Ruiz and Rondan (2008) see the fairness of prices influenced by three things, namely: the price of goods in the past, prices offered by competitors, and prices set by the company. Githiri (2018) states that loyal consumers see the addition of relatively low prices as a natural thing, but not that it is inversely proportional to consumers who are not loyal. According to Virvilaite et al. (2009) states that there is a close relationship between fairness of prices and customer loyalty. Asadi et al. (2014) also found the same results where the perceived fairness of prices had a positive relationship both directly and indirectly (through customer satisfaction) to customer loyalty. Fairness of prices means a situation where consumers feel a comparison between the benefits received and the level of satisfaction obtained; and the price offered can be accepted according to the provisions (Marina et al., 2016).

Subroto and Rahayu (2014) state that consumer trust has a significant positive effect on consumer loyalty. Akbar and Parvez (2009: 26) state that trust only exists when one party believes in a cooperative relationship that is reliable and has integrity. Trust is the belief that someone will find what he wants in others, and not what he feared.

Dias et al. (2012) state that if a company already has loyal customers, the company's economic income will be guaranteed by regular cash flows. Product loyalty will form over time. The concentration of formation 
and development of loyalty, at first, already exists in products related to services (Shahroudi and Naimi, 2014).

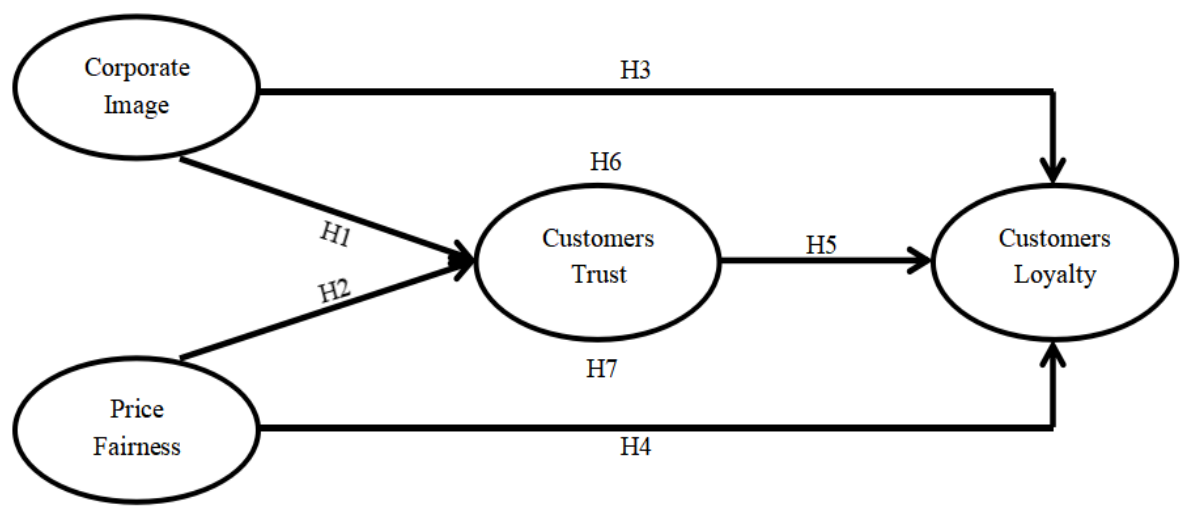

Figure 1. Conceptual Framework

\section{Hypothesis}

\section{The Effect of Corporate image on Customer Loyalty}

According to Li and Chaipoopirutana (2014) concluded that there is a significant positive relationship between brand image and brand loyalty. The results illustrate that if the customer brand image is positive and high, purchase intention or brand loyalty will be high. According to Leonnard et al. (2014) Image has a significant effect on loyalty. This finding shows that a good image can significantly encourage customers to be loyal. Based on research conducted by Widiyanto and Toro (2012), Costa and Chaipoopirutana (2014), and Subroto and Rahayu (2014) it was stated that corporate image has a significant positive effect on customer loyalty. Kim and Lee (2010) also state that corporate image has an important role in building and maintaining customer loyalty in the market. This description is the basis for developing the proposed hypothesis, namely:

H1: Corporate image has a positive and significant effect on customer loyalty

\section{The Effect of Price Fairness on Customer Loyalty}

Virvilaite et al. (2009) states that there is a close relationship between price fairness and customer loyalty. Kurniasih (2012) also found the same results where the perception of price fairness has a positive relationship both directly and indirectly (through customer satisfaction) to customer loyalty. Kaura et al. (2015) in his research found that there is a relationship between price fairness and satisfaction and loyalty to service companies. Nazari et al. (2014) found that price fairness has a direct effect on customer loyalty 
without going through price satisfaction and customer satisfaction. The results of this study, namely the price fairness has a positive effect on customer loyalty. This is the basis for developing the proposed hypothesis, namely:

H2: Price fairness has a positive and significant effect on customer loyalty.

\section{The Effect of Corporate image on Customer Trust}

According to Widiyanto and Toro (2012) corporate image (corporate image) has a significant effect on trust. According to Nguyen et al. (2013) imagery is considered a source of trust so that, corporate image can be seen as an important publicity tool that tends to strengthen customer trust. Whereas according to Leonnard et al. (2014) Image does not have a significant effect on trust, these findings indicate that a positive image will not have an impact on the escalation of trust. This is the basis for developing the proposed hypothesis, namely:

H3: Corporate image has a positive and significant effect on customer trust

\section{The Effect of Price fairness on Customer Trust}

Most customers are usually as positive as prices, but also consider other factors such as brand image, location, service, features and product quality. In addition, customer perceptions of brand selection among competing alternatives are often effect by a price, Khandelwal and Bajpai (2012). A reasonable price will give trust to customers to shop. Haghighi et al. (2012) states that price fairness has a significant positive effect on customer trust. This is contrary to Anuwichanont et al. (2009) which states that price behavior has absolutely no effect on satisfaction and trust, while monetary prices have an effect only solely on satisfaction. According to Leonnard et al. (2014) prices do not have a significant effect on trust, these results indicate that costs do not always effect trust. This description is the basis for developing the proposed hypothesis, namely:

H4: Price fairness has a positive and significant effect on customer trust.

\section{The Effect of Customer Trust on Customer Loyalty}

Anuwichanont et al. (2009), Doong et al. (2010), Nguyen et al. (2013), Costa and Chaipoopirutana (2014), and Subroto and Rahayu (2014) state that customer trust has a significant positive effect on customer loyalty. Li and Chaipoopirutana (2014) concluded that there was a low positive relationship between brand trust and brand loyalty. Teenagers may trust some brands, but not for a long time. If the company makes a few small mistakes, even young people can feel uncomfortable with the brand, and they will easily switch 
to other brands. Contrary to research conducted by Haghighi et al. (2012), Widiyanto and Toro (2012), and Leonnard et al. (2014) which states that trust does not have a significant effect on customer loyalty. This description is the basis for developing the proposed hypothesis, namely:

H5: Customer trust has a positive and significant effect on customer loyalty.

\section{The Role of Customer Trust as a Mediation Variable Corporate Image between Customer Loyalty}

Vuuren et al. (2012) stated that image is one of the elements that enables the building of a trust relationship, where sincere trust can lead to customer loyalty. In line with Vuuren, research conducted by nurfarida and Dianawati (2016) in Toyota car companies got the results that the company's image was able to build a trust and trust as a mediating factor that was able to create customer loyalty with the company's image. Nguyen (2013) also stated that trust plays a role in creating customers, where turst has a mediating role in corporate image to increase customer loyalty. This description is the basis for developing the proposed hypothesis, namely:

H6: Customer trust mediates the relationship between corporate image and customer loyalty.

\section{The Role of Customer Trust as a Mediation Variable Price Fairness between Customer Loyalty}

A price that is formed is high where this means that the fairness of high prices will make a high value on the product, so it will form a picture of product quality and the creation of high trust and further increase in loyalty (Fata, 2015). It can be concluded that with satisfaction and trust in prices, tourists will become loyal tourists in using Booking.com services (Wulandari et al., 2016). This description is the basis for developing the proposed hypothesis, namely:

H7: Customer trust mediates the price fairness to customer loyalty.

\section{Methods}

The instrument used to collect data is a questionnaire consisting of a set of statements to measure the variables that have been determined. The population in this study is customers who in the past year have been shopping online at Mapemall.com at least twice, who live in the area of Denpasar City, whose numbers cannot be calculated definitively (infinite). The analysis tool used in this study is Structural Equation Modeling-Partial Least Square (SEM-PLS), so the minimum sample size recommended is from 30 to 100 samples (Ghozali, 2012). In Ferdinand (2011: 173), it is stated that SEM analysis requires a sample of at least 5 times the number of parameter variables (indicators) to be analyzed. In this study, the total 
number of indicators to be analyzed is 17 indicators, thus the minimum number of samples to be examined is as many as 17 indicators multiplied by 5 which are as many as 85 samples.

\section{Results}

This study uses dominant customers, female than male, namely 52 people or $61.2 \%$. If based on age, customers aged 25-30 years are the most among the others, namely 45 people or $53.0 \%$. In this study respondents when viewed in terms of recent education, the customers with the latest S1 education were the most dominant among the others, namely 55 people or $64.7 \%$. Based on Table 5.1 , it can be seen that the most dominant customer profession is as many as 59 employees or $69.4 \%$. From the average expenditure / month, the dominant customer with an average expenditure of Rp. 3,000,000 - Rp. 5,000,000 as many as 37 people or $43.5 \%$.

\section{Validity Testing Result}

Table 1. Validity Testing Result

\begin{tabular}{ccccc}
\hline Variabel & Indikator & Koefisien Korelasi & Korelasi Batas & Keterangan \\
\hline & $\mathrm{X}_{1.1}$ & 0,712 & 0,361 & Valid \\
Corporate Imae $\left(\mathrm{X}_{1}\right)$ & $\mathrm{X}_{1.2}$ & 0,788 & 0,361 & Valid \\
& $\mathrm{X}_{1.3}$ & 0,788 & 0,361 & Valid \\
& $\mathrm{X}_{1.4}$ & 0,670 & 0,361 & Valid \\
& $\mathrm{X}_{1.5}$ & 0,717 & 0,361 & Valid \\
& $\mathrm{X}_{2.1}$ & 0,733 & 0,361 & Valid \\
Price Fairness $\left(\mathrm{X}_{2}\right)$ & $\mathrm{X}_{2.2}$ & 0,730 & 0,361 & Valid \\
& $\mathrm{X}_{2.3}$ & 0,747 & 0,361 & Valid \\
& $\mathrm{X}_{2.4}$ & 0,721 & 0,361 & Valid \\
& $\mathrm{Y}_{1.1}$ & 0,748 & 0,361 & Valid \\
Customer Trust $\left(\mathrm{Y}_{1}\right)$ & $\mathrm{Y}_{1.2}$ & 0,729 & 0,361 & Valid \\
& $\mathrm{Y}_{1.3}$ & 0,782 & 0,361 & Valid \\
& $\mathrm{Y}_{1.4}$ & 0,722 & 0,361 & Valid \\
& $\mathrm{Y}_{1.5}$ & 0,765 & 0,361 & Valid \\
& $\mathrm{Y}_{2.1}$ & 0,725 & 0,361 & Valid \\
Customer Loyalty $\left(\mathrm{Y}_{2}\right)$ & $\mathrm{Y}_{2.2}$ & 0,766 & 0,361 & Valid \\
& $\mathrm{Y}_{2.3}$ & 0,783 & 0,361 & Valid \\
\hline
\end{tabular}

All research instruments used to measure corporate image variables, price fairness, customer trust and customer loyalty have a correlation coefficient value with a total score of all statement items greater than 0.361. This shows that the items in the research instrument are valid and appropriate to be used as research instruments. 


\section{Reliability Testing Result}

Table 2. Reliability Test

\begin{tabular}{clcc}
\hline No. & \multicolumn{1}{c}{ Variabel } & Cronbach's Alpha & Keterangan \\
\hline 1 & Corporate Image $\left(\mathrm{X}_{1}\right)$ & 0,785 & Reliabel \\
2 & Price Fairness $\left(\mathrm{X}_{2}\right)$ & 0,709 & Reliabel \\
3 & Customer Trust $\left(\mathrm{Y}_{1}\right)$ & 0,803 & Reliabel \\
4 & Customer Loyalty $\left(\mathrm{Y}_{2}\right)$ & 0,625 & Reliabel \\
\hline
\end{tabular}

Primary Data, 2019

All research instruments have a Cronbach's Alpha coefficient of more than 0.6. So it can be stated that all variables have met the requirements of reliability or reliability so that they can be used to conduct research.

\section{R-Square}

Table 3. R-square Testing Result

\begin{tabular}{|l|l|l|}
\hline & R Square & R Square Adjusted \\
\hline Customer Trust (Y1) & 0.716 & 0.709 \\
\hline Customer Loyal (Y2) & 0.683 & 0.671 \\
\hline
\end{tabular}

Primary Data, 2018

Based on the table above, the R-square value is obtained for the corporate image variable and the price fairness towards customer loyalty is 0.683 which indicates that it has a large effect of $0.683 \times 100 \%=68.3 \%$. The R-square value for the corporate image variable and the price fairness against customer trust is 0.716 which indicates that it has a large effect of $0.716 \times 100 \%=71.6 \%$.

\section{Q-Square}

Inner model testing is done by looking at the Q-square value which is a test of the model's goodness of fit. If the Q-square value is greater than 0 (zero), it shows that the model has a predictive relance value, while the Q-square value less than 0 (zero) shows that the model lacks predictive relevance. However, if the calculation results show a Q-square value of more than 0 (zero), then the feasible model is said to have a relevant predictive value. The Q-square calculation can be seen as follows:

$$
\begin{aligned}
& \mathrm{Q} 2=1-[(1-\mathrm{R} 12)(1-\mathrm{R} 22)] \\
& \mathrm{Q} 2=1-[(1-0,716)(1-0,683)] \\
& \mathrm{Q} 2=1-[(0,284)(1-0,317)] \\
& \mathrm{Q} 2=1-(0,090) \\
& \mathrm{Q} 2=0,909
\end{aligned}
$$

Based on the above calculations, obtained a Q-square value of 0.909 more than 0 , so it can be concluded that the model has predictive value relevance or a decent model is said to have relevant predictive value.

\section{Direct Effect}


Table3. Direct Effect

\begin{tabular}{|l|r|r|r|r|r|}
\hline & \multicolumn{1}{|l|}{$\begin{array}{l}\text { Original } \\
\text { Sample } \\
\text { (O) }\end{array}$} & \multicolumn{1}{l|l}{$\begin{array}{l}\text { Sample } \\
\text { Mean } \\
\text { (M) }\end{array}$} & $\begin{array}{l}\text { Standard } \\
\text { Deviation } \\
\text { (STDEV) }\end{array}$ & $\begin{array}{l}\text { T Statistics } \\
(\mid \mathbf{O} / \text { STDEV|) }\end{array}$ & P Values \\
\hline $\begin{array}{l}\text { Corporate Image (X1) ->Customer } \\
\text { Trust (Y1) }\end{array}$ & 0.528 & 0.529 & 0.124 & 4.265 & $\mathbf{0 . 0 0 0}$ \\
\hline $\begin{array}{l}\text { Corporate Image (X1) ->Customer } \\
\text { Loyalty (Y2) }\end{array}$ & 0.511 & 0.511 & 0.108 & 4.716 & $\mathbf{0 . 0 0 0}$ \\
\hline $\begin{array}{l}\text { Customer Trust (Y1) ->Customer } \\
\text { Loyalty (Y2) }\end{array}$ & 0.362 & 0.360 & 0.105 & 3.459 & $\mathbf{0 . 0 0 1}$ \\
\hline $\begin{array}{l}\text { Price Fairness (X2) ->Customer Trust } \\
\text { (Y1) }\end{array}$ & 0.385 & 0.385 & 0.138 & 2.793 & $\mathbf{0 . 0 0 5}$ \\
\hline $\begin{array}{l}\text { Price Fairness (X2) ->Customer } \\
\text { Loyalty (Y2) }\end{array}$ & 0.683 & 0.682 & 0.076 & 9.028 & $\mathbf{0 . 0 0 0}$ \\
\hline
\end{tabular}

Primary Data, 2018

\section{H1: corporate image has a positive and significant effect on customer loyalty}

Testing the hypothesis with the PLS approach produces path coefficients a direct effect of corporate image on customer loyalty with the Original Sample value of 0.511 and P-Values of 0,000 . Original Value Samples show a positive correlation between corporate image and customer loyalty. The P-Values value of 0,000 is less than $0.05(0,000<0,05)$ indicating that the corporate image has a significant effect on customer loyalty. Thus the results of statistical data analysis show that the corporate image has a positive and significant effect on customer loyalty. The results of this study are in accordance with the results of previous studies by $\mathrm{Li}$ and Chaipoopirutana (2014), concluding that there is a significant positive relationship between brand image and brand loyalty. The results illustrate that if the customer brand image is positive and high, purchase intention or brand loyalty will be high. The results of this study are also in accordance with the results of the study of Leonnard et al. (2014) which states that the image has a significant effect on loyalty. This finding shows that a good image can significantly encourage customers to be loyal. These results are also in line with the research conducted by Widiyanto and Toro (2012), Costa and Chaipoopirutana (2014), and Subroto and Rahayu (2014) which state that corporate image has a significant positive effect on customer loyalty. Kim and Lee (2010) also state that corporate image has an important role in building and maintaining customer loyalty in the market.

\section{H2: price fairness has a positive and significant effect on customer loyalty}

Testing the hypothesis with the PLS approach produces a path coefficient of the direct effect of price fairness on customer loyalty with an Original Sample value of 0.683 and P-Values of 0,000 . The Original Sample value shows a positive correlation between price fairness and customer loyalty. The P-Values value is 0,000 which is less than $0.05(0,000<0,05)$ indicating the price fairness has a significant effect on customer loyalty. Thus the results of statistical data analysis indicate that the price fairness has a positive and significant effect on customer loyalty. The results of this study are consistent with the results of previous studies by Virvilaite et al. (2009) states that there is a close relationship between price fairness and customer loyalty. Kurniasih (2012) also found the same results where the perception of price fairness has a positive relationship both directly and indirectly (through customer satisfaction) to customer loyalty. The results of this study are also in accordance with Kaura et al. (2015), who in his research found that there was a relationship between price fairness and satisfaction and loyalty to service companies. And the results of this study are also in line with the results of research by Nazari et al. (2014), who found that price fairness has a direct effect on customer loyalty without going through price satisfaction and customer satisfaction. The results of this study, namely the price fairness has a positive effect on customer loyalty. 


\section{H3: corporate image has a positive and significant effect on customer trust}

Testing the hypothesis with the PLS approach produces path coefficients a direct effect of corporate image on customer trust with an Original Sample value of 0.528 and P-Values of 0,000. Original Value Samples show a positive correlation between corporate image and customer trust. The P-Values value is 0,000 which is less than $0.05(0,000<0,05)$ indicating that the corporate image has a significant effect on customer trust. Thus the results of statistical data analysis show that the corporate image has a positive and significant effect on customer trust. The results of this study in accordance with the results of previous studies by Widiyanto and Toro (2012) corporate image (corporate image) have a significant effect on trust. These results are also in accordance with Nguyen et al. (2013), image is considered as a source of trust so that, corporate image can be seen as an important publicity tool that tends to strengthen customer trust. The results of this study contradict Leonnard et al. (2014) which states that the image does not have a significant effect on trust, these findings indicate that a positive image will not have an impact on the escalation of trust.

\section{H4: price fairness has a positive and significant effect on customer trust}

Testing the hypothesis with the PLS approach produces path coefficients the direct effect of price fairness on customer trust with the Original Sample value of 0.385 and P-Valuesof 0.005. Original Sample value shows a positive correlation between price fairness and customer trust. P-Values of 0.005 which is less than $0.05(0.005<0.05)$ shows the price fairness has a significant effect on customer trust. Thus the results of statistical analysis show that price fairness has a positive and significant effect on customer trust. The results of this study are in accordance with the results of previous studies by Haghighi et al. (2012), which states that price fairness has a significant positive effect on customer trust. This is contrary to Anuwichanont et al. (2009) which states that price behavior has absolutely no effect on satisfaction and trust, while monetary prices have an effect only solely on satisfaction. According to Leonnard et al. (2014) prices do not have a significant effect on trust, these results indicate that costs do not always effect trust.

\section{H5: customer trust has a positive and significant effect on customer loyalty}

Testing the hypothesis with the PLS approach produces path coefficients a direct effect on customer trust in customer loyalty with an Original Sample value of 0.362 and P-Values of 0.001. Original Sample Value shows a positive correlation between customer trust and customer loyalty. P-Values, value of 0.001 which is less than $0.05(0.001<0.05)$ indicates that customer trust has a significant effect on customer loyalty. Thus the results of data analysis statistically show that customer trust has a positive and significant effect on customer loyalty. The results of this study are in accordance with the results of previous studies by Anuwichanont et al. (2009), Doong et al. (2010), Nguyen et al. (2013), Costa and Chaipoopirutana (2014), and Subroto and Rahayu (2014) which state that customer trust has a significant positive effect on customer loyalty. Li and Chaipoopirutana (2014) concluded that there was a low positive relationship between brand trust and brand loyalty. Teenagers may trust some brands, but not for a long time. If the company makes a few small mistakes, even young people can feel uncomfortable with the brand, and they will easily switch to other brands. The results of this study contradict the research conducted by Haghighi et al. (2012), Widiyanto and Toro (2012), and Leonnard et al. (2014) which states that trust does not have a significant effect on customer loyalty. 
Indirect Effect

Tabel 3. Indirect Effect

\begin{tabular}{|c|c|c|c|c|c|}
\hline & $\begin{array}{l}\text { Original } \\
\text { Sample } \\
\text { (O) }\end{array}$ & $\begin{array}{l}\text { Sample } \\
\text { Mean } \\
\text { (M) }\end{array}$ & $\begin{array}{l}\text { Standard } \\
\text { Deviation } \\
\text { (STDEV) }\end{array}$ & $\begin{array}{l}\text { T Statistics } \\
\text { (|O/STDEV|) }\end{array}$ & $\begin{array}{l}\mathbf{P} \\
\text { Values }\end{array}$ \\
\hline $\begin{array}{l}\text { Corporate Image (X1) ->CCustomer } \\
\text { Trust (Y1) ->Customer Loyalty (Y2) }\end{array}$ & 0.191 & 0.191 & 0.075 & 2.558 & 0.011 \\
\hline $\begin{array}{l}\text { Price Fairness (X2) ->Customer Trust } \\
\text { (Y1) ->CCustomer Loyalty (Y2) }\end{array}$ & 0.139 & 0.139 & 0.063 & 2.202 & 0.028 \\
\hline
\end{tabular}

Primary Data, 2018

H6: customer trust mediates the corporate image relationship to customer loyalty

The value of the p-value of the corporate image variable on customer loyalty through customer trust is 0.011 . Because the p-value is less than $0.05(0.011<0.05)$ with an original sample value of positive 0.191 , it can be concluded that customer trust is able to mediate positively and significantly the effect of corporate image on customer loyalty.

The mediating role test of customer trust in the effect of corporate image on customer loyalty can also be done by examining the coefficient of direct effect of exogenous variables on endogenous variables in the model involving mediating variables. The results of the mediation test have shown that according to the criteria for the effect of exogenous variables on mediating variables (corporate image on customer trust) that is $(0,000<0,05)$ is significant, the effect of mediating variables on endogenous variables (customer trust in customer loyalty) is $(0.001<0.05)$ is significant, the direct effect of exogenous variables on endogenous variables (corporate image on customer loyalty) on the model involving mediating variables $(0,000<0,05)$ is significant, it can be said to be partial mediation. Thus, trust as a partial mediation between the effect of corporate image on customer loyalty.

Based on the description, then hypothesis 6 which states that customer trust mediates the relationship of corporate image to customer loyalty is accepted.

\section{H7: customer trust mediates the price fairness relationship to customer loyalty}

The value of the p-value price fairness variable towards customer loyalty through customer trust is 0.028 . Because the $p$-value is less than $0.05(0.028<0.05)$ with an original sample value of positive 0.139 , it can be concluded that customer trust is able to positively mediate and significantly effect the price fairness on customer loyalty.

The test of the mediating role of customer trust in the effect of price fairness on customer loyalty can also be done by examining the coefficient of direct effect of exogenous variables on endogenous variables in the model involving mediating variables. The results of the mediation test have shown that according to the criteria of the effect of exogenous variables on the mediating variable (price fairness on customer trust) that is $(0.005<0.05)$ is significant, the effect of mediating variables on endogenous variables (customer trust in customer loyalty) is $(0.001<0.05)$ is significant, the direct effect of exogenous variables on endogenous variables (price fairness on customer loyalty) in the model involving mediating variables $(0,000<0,05)$ is significant, it can be said to be partial mediation. Thus, trust as a partial mediation between the effect of price fairness on customer loyalty. 
Based on the description, hypothesis 7 which states that customer trust mediates the price fairness relationship to customer loyalty is accepted.

\section{Conclusion}

The corporate image has a positive and significant effect on the trust of Mapemall.com customers. This means that if the corporate image increases, then the trust of Mapemall.com customers will increase as well. Price fairness has a positive and significant effect on customer trust in Mapemall.com. This means that if the price fairness increases, the trust of Mapemall.com customers will increase as well. Corporate image has a positive and significant effect on customer loyalty at Mapemall.com. This means that if the corporate image increases, then the loyalty of Mapemall.com customers increases as well. Price fairness has a positive and significant effect on customer loyalty in Mapemall.com. This means that if the price fairness increases, then the loyalty of Mapemall.com customers will increase as well. Customer trust has a positive and significant effect on customer loyalty at Mapemall.com. This means that if customer trust increases, Mapemall.com customer loyalty increases. Customer Trust is able to mediate the effect of corporate image on customer loyalty in Mapemall.com. This means that the trust of Mapemall.com customers can strengthen the effect of corporate image on Mapemall.com customer loyalty. Customer trust is able to mediate the effect of price fairness on customer loyalty in Mapemall.com. This means that the fairness of Mapemall.com price can strengthen the effect of price fairness on customer loyalty mapemall.com.

Based on the results of the study, it shows that the corporate image variable has the highest effect on customer trust, compared to the price fairness variable. Thus, it is suggested to the management to pay more attention to the company's image. This is because customers make the corporate image the main measure of trust in an online store. In this case, the indicator of the corporate image that needs to be improved is the indicator "Mapemall.com has a good track record", where the indicator shows the lowest number of respondents' answers which means that the reputation of Mapemall.com should be improved again.

Based on the results of the study, it shows that the price fairness variable has the highest effect on customer loyalty, compared to corporate image variables and customer trust. Thus it is recommended that the management pay more attention to the price fairness of the products offered by the company. This is because customers make the price fairness the main measure of loyalty to an online store. In this case, the indicator of the fairness of the price that needs to be improved is the indicator "prices of products at Mapemall.com compete with similar products in other online shops", where the indicator shows the lowest

number of respondents' answers which means that the price of Mapemall.com must be more competitive with the prices of similar products in other online shops.

\section{References}

Abdel-Salam, A.M., A. Al-Dekheil, A. Babkr, M. Farahna and H.M. Mousa. 2010. High Fiber Probiotic Fermented Mare's Milk Reduces The Toxic Effects of Mercury in Rats. North Am. J. Med. Sci., Vol. 12, pp: 569-575.

Akbar, Mohammad Muzahid dan Noorjahan Parvez. 2009. Impact Of Service Quality, Trust, and Customer Satisfaction On Customers Loyalty. ABAC Journal, Vol. 29, No.1, pp: 24-38. 
Anuwichanont, J., dan Mechinda, P. 2009. The Impact Of Perceived Value On Spa Loyalty and Its Moderating Effect of Destination Equity. Journal of Business \& Economics Research,Vol. 7, No. 12, pp: 73-90.

Ananta Wijaya, I Putu Surya, Nurcaya, I Nyoman. 2017. Kepuasan Pelanggan Memediasi Kualitas Produk dan Kewajaran Harga Terhadap Loyalitas Merek Mcdonalds di Kota Denpasar. E-Jurnal Manajemen Unud, Vol. 6, No. 3, pp: 1534-1563.

Asadi, A., dan Pool, J. K. 2014. The effect of perceived price fairness through satisfaction and loyalty on international tourists' price acceptance of Islamic-Iranian art products. Education, Business and Society: Contemporary Middle Eastern, Vol, 7, No. 4, pp: 201-215.

Bayraktar, E., Tatoglu, E., Turkyilmaz, A., Delen, D., Zaim, s. 2012. Measuring the efficiency of customer satisfaction and loyalty for mobile phone brands with DEA. International Journal of Expert Systems with Applications, Vol. 39, pp: 99-106.

Chiu, K. H., Hsu, C. L. 2010. Research On The Connections Between Corporate Social Responsibility and Corporation Image In The Risk Society: Take The Mobile Telecommunication Industry as An Example. International Journal of Electronic Business Management, Vol. 8, No. 3,pp: 183-194

Consuegra, David Martin, Arturo Molina dan Agueda Esteban. 2007. An Integrated Model Of Price, Satisfaction And Loyalty : An Empirical Analysis in The Service Sector. Journal of Product E Brand Management, Vol. 16, No. 7, pp: 459-468

Costa, C.P. Chaipoopirutana, S. 2014. A Study of the Antecedents of Customer Loyalty towars and Internet Service Psrovider in Timor-Leste. International Conference on Business, Law and Corporate Social Responsibility, Vol. 1, No. 2, pp: 36-40

Daryanto, dan Setyobudi, I. 2014. Konsumen dan Pelayanan Prima. Yogyakarta: Gava Media.

Deng, Z., Lu, Y., Wei, K. K., \& Zhang, J. 2010. Understanding customer satisfaction and loyalty: An empirical study of mobile instant messages in China. International Journal of Information Management, Vol. 30, No. 4, pp: 289-300.

Dias W.,Hidayat, W., dan Dewi, Reni Shinta. 2012. Pengaruh Kualitas Pelayanan, dan Harga Terhadap Kepuasan Konsumen Study Pada Hotel Pandanaran Semarang. Journal Of Social and Politic, Vol. 1, No. 2, pp: 1-16.

Dimyati, M. dan Subagio, N.A. 2016. Impact of Service Quality, Price, and Brand on loyalty with the Meditation of Customer Satisfaction On pos Ekpres in East Java. Mediterranean Journal of Social Sciences, Vol. 7, No. 4, pp: 74-86.

Doong, H-S., Wang, H-C., Shih, H-C. 2008. Exploring Loyalty Intention in the Electronic Marketplace. Journal of Electronic Markets, Vol. 18, No. 2, pp: 142-149.

Fata, Khairul. 2015. Pengaruh Harga, Citra Merek, Dan Fitur Terhadap Kepuasan pelanggan Serta Dampaknya Pada Loyalitas Merek (Studi Kasus Produk Handphone Samsung Di Banda Aceh). Jurnal Kebangsaan, Vol. 4, No.7, pp: 40-46. 
Ferdinand, A., 2011. Metode Penelitian Manajemen, Pedoman Penelitian untuk Penulisan Skripsi, Tesis dan Disertasi Ilmu Manajemen. Semarang : BP. UNDIP.

Ghozali, Imam. 2012. Aplikasi Analisis Multivariate Dengan Program IBM SPSS 20. Semarang: Badan Penerbit Universitas Diponegoro.

Githiri, Margaret. 2018. An Examination of The Relationship Between Perceived Price Fairness on Customer Satisfaction and Loyalty in Kenyan Star-Rated Restaurants. International Journal of Scientific Research and Management, Vol. 6, No. 10.

Gumussoy, C. A., dan Koseoglu, B. 2016. The Effects of Service Quality, Perceived Value and Price Fairness on Hotel Customers' Satisfaction and Loyalty. Journal of Economics, Business and Management. Vol. 4, No. 9, pp. 523-527.

Gregory, J. R., Wiechmann, J. G. 2011. Marketing Corporate Image: The Company as Your Number One Product. McGraw-Hill, New York.

Guo Li, Xian, Wang, X., Juan Cai, Y. 2011. Corporate-, Product-, and user-Image dimensions and Purchase Internet The Mediating Role of Cognitive and Affective Attitudes. Journal of Computer,Vol. 6, No. 9,pp: 1875-1879

Haghighi, M. Dorosti, A. Rahnama, A. Hoseinpour, A. 2012. Evaluation of Factors Affecting Customer Loyalty in The Restaurant Industry. African Journal of Business Management, Vol. 6, No. 14, pp: 50395046.

Hassan, M., Hassan, S., Nawaz, M. S., dan Aksel, I. 2013. Measuring Customer Satisfaction and Loyalty Through Service Fairness, Service Quality and Price Fairness Perception: An Empirical Study Of Pakistan Mobile Telecommunication Sector. Sci.Int.(Lahore), Vol. 25, No. 4, pp 895-904.

Herawaty, T., Tresna, P. W., dan Wisudastuti, F. E. 2016. Pengaruh Price Fairness dan Service Fairness Terhadap Customer Satisfaction Pada Go-Jek. Jurnal AdBispreneur, Vol. 1, No. 3, pp: 231-241.

Hussein , A. S., dan Hapsari, R. 2014. How Quality, Value And Satisfaction Create Passenger Loyalty: An Empirical Study On Indonesia Bus Rapid Transit Passenger. The International Journal of Accounting and Business Society, Vol. 22, No. 2, pp. 95-114.

Hidayat, Rachmat. 2009. Pengaruh Kualitas Layanan, Kualitas Produk dan Nilai Nasabah Terhadap Kepusan dan Loyalitas Nasabah Bank Mandiri. Jurnal Manajemendan Kewirausahaan, Vol. 11, No. 1, pp: $59-72$.

Hurriyati, R. 2010. Bauran Pemasaran dan Loyalitas Konsumen. Bandung: ALFABETA.

Iqbal, M. dan Shah, A. B. A. 2016. The Impact of Customer Satisfaction on Customer Loyalty: Mediating Role of Customer Trust. Journal of Business Management and Economic Studies. Vol. 1, No. 1, pp: 1-15.

Ishaq, M. I., Bhutta, M. H., Hamayun, A. A., Danish, R. Q., dan Hussain, N. M. 2014. Role of Corporate Image, Product Quality and Customer Value in Customer Loyalty: Intervening Effect of Customer Satisfaction. J. Basic. Appl. Sci. Res., Vol 4, No. 4. Pp 89-97. 
Jahanshahi, Asghar Afshar; Mohammad Ali Hajizadeh Gashti; Seyed Abbas Midarmadi; Khaled Nawaser. 2011. Study the Effects of Customer Service and Product Quality on Customer Satisfaction and Loyalty. International Journal of Humanities and Social Science, Vol. 1 No. 7, pp: 253 - 260.

Jakpar, S., Sze Na, Angelyn G., Johari, A., and Myint, Khin T. 2012. Examining the product quality Attributes that Influences Customer satisfavtion most when the price Was Discounted: a case Study in Kuching Sarawak. International Journal of business and Social Science, Vol. 3, No. 23, pp: 221-236.

Kartika Sari, R., Yulisetriani, D., dan Sudaryanto. 2016. Pengaruh Harga dan Kualitas Pelayanan Serta Kualitas Produk Terhadap Minat Pembelian Ulang dan Kepuasan Pelanggan Online Shopping Pada Mahasiswa Universitas Abdurachman Saleh Situbondo. Jurnal Bisnis dan Manajemen, Vol. 10, No. 2, pp: 115-126.

Kapoor, C., and Solomon, N. 2011. Understanding and Managing Generational differences in the Workplace. Worldwide Hospitality and Tourism, Vol. 3, No. 4, pp: 308-318

Kaura, V., Prasad, C. S. D., dan Sharma, S. 2015. Service quality, service convenience, price and fairness, customer loyalty, and the mediating role of customer satisfaction. International Journal of Bank Marketing, Vol. 33, No. 4, pp: 404-422.

Khandelwal, U., Bajpai, N. 2012. Price fairness and Its linear Dependence on Consumer Attitude: A Comparative Study in Metro and Non Metro City. European Journal of Business and Management, Vol. 4, No. 10, pp: 94-101.

Kheng, L.L., Mahammad, O., Ramayah, T. 2010. The Impact of Service Quality on Customer Loyalty: A Study of Banks in Penang, Malaysia. International Journal of Marketing Studies. Vol. 2, No. 2, pp: 5766.

Kim, Y.E., Lee, J. W. 2010. Relationship Between Corporate Image and Customer Loyalty in Mobile Communication Service Markets. Africa Journal of Business Management, Vol. 4, No. 18, pp: 4035-4041

Kotler, P., dan Keller, K.L. 2009. Manajemen Pemasaran Edisi 13. Jilid I. Jakarta: Indeks

Kotler, P., dan Keller, K. L. 2012. Marketing Management. 14th edition. New Jersey: Pearson Prentice Hall.

Kurniasih, Indah Dwi. 2012. Pengaruh Harga dan Kualitas Pelayanan Terhadap Loyalitas Pelanggan Melalui Variabel Kepuasan (Studi Pada Bengkel AHASS 0002-ASTRA Motor SILIWANGI SEMARANG). Jurnal Administrasi Bisnis, Vol. 1,No. 1,pp: 37-45.

Kurniawan, F., Arifin, Z., Fanani, D. 2018. Pengaruh Citra Merek terhadap Keputusan Pembelian (Survei kepada para siswa SMAN 15 Surabaya kelas XII yang menggunakan laptop bermerk ASUS). Jurnal Administrasi Bisnis (JAB), Vol. 56, No. 1, pp: 75-81.

Leonnard, MComm, Heny K.S. Daryanto, Dadang Sukandar, Eva Z.Y. 2013. The Loyalty Model Of private University Student Study Case: STIKOM London School of Piblic Relation. International Journal of Information Technology and Business Management, Vol. 20, No. 1, pp: 70-89.

Leonnard, MComm, Heny K.S. Daryanto, Dadang Sukandar, Eva Z.Y. 2014. The Loyalty Model Of private University Student. International Research Journal of Business Studies, Vol. 7, No. 1, pp: 55-68. 
Lesmana, R., Yustriani. 2017. Pengaruh Citra Perusahaan Terhadap Keputusan Pembelian Konsumen PT. Garuda Indonesia Tbk. (Persero). Jurnal Ilmiah Manajemen Forkamma, Vol. 1, No. 1,pp: 134-147.

Li, Z. dan Chaipoopirutana, S. 2014. The Important Factors That Influence On Buiding Brand Loyalty Towards Chang'an Car Brand In Xi'an City, Saanxi, China. International Conference on Business, Law and Corporate Social Responsibility, Vol. 1, No.1, pp: 1-14.

Lovelock, C., dan Wirtz, J. 2011. Service Marketing. New Jersey, USA: Pearson.

Mahmud, A., Jusoff, K., dan Hadijah, S. 2013. The Effect of Service Quality and Price on Satisfaction and Loyalty of Customer of Commercial Flight Service Industry. World Applied Sciences Journal. Vol. 23, No. 3, pp. 354- 359.

Marina, S., Kartini, D., Sari, D., dan Padmasasmita, S. 2016. customer loyalty as the implications of price fairness determined by relationship marketing and service quality of airline services. South East Asia Journal of Contemporary Business, Economics and Law, Vol. 11, No. 2, pp: 43-51.

Meskaran, Fatemeh., Ismail, Zuraini., and Shanmugam, Bharani. 2013. Online Purchase Intention: Effects of Trust and Security Perception. Australian Journal of Basic and Applied Sciences, Vol. 7, No. 6, pp: 307315.

Minar, D., Safitri, A. 2017. Brand image and Product Quality on Customer Loyalty (Survey in Cekeran Midun). Trikonomika, Vo. 16, No. 1, pp: 43-50.

Mullins, John W dan Walker Jr, Orville C. 2013. Marketing Management: A Strategic Decision-Making Approach, 8th Edition. McGraw-Hill International Edition.

Nazari, M., Hosseini, M.A.S., Kalejahi, S. V. T. 2014. Impact Of Price Fairness on Price Satisfaction, Customer Satisfaction and Customer Loyalty in iran Telecommunication Market (Case: MTN Irancell Company). Asian Journal of Research in Marketing, Vol. 3, No. 1, pp: 131-144.

Nguyen Minh Tuan, 2012. Effects of Service Quality and Price Fairness on Student Satisfaction. International Journal of Business and Social Science.Vol. 3, No. 19, pp: 1-19.

Nguyen Nha, Leclerc, A. LeBlanc, G. 2013. The Mediating Role of Customer Trust on Customer Loyalty. Journal of Service Science and Management, Vol. 6, pp: 96-109

Oliver, R. L. 2015. Satisfaction: A Behavioral Perspective on the Consumer. New York: Routledge.

Pantouvakis, A., dan Bouranta, N. 2014. Quality and price - impact on patient satisfaction. International Journal of Health Care Quality Assurance,Vol. 27, No. 8, pp. 684-696.

Purba, Roy Parto, Ibrahim, Mariaty. 2017. Pengaruh Citra Perusahaan Terhadap Loyalitas Pelanggan (Studi Kasus PT. Bintang Utara Perwakilan Dolok Sanggul). Jom Fisis, Vol. 4, No. 1, pp: 1-13.

Rahyuda, I K., dan Atmaja, N. P. C. D. 2011. Pengaruh Kewajaran Harga, Citra Perusahaan Terhadap Kepuasan Dan Loyalitas Pengguna Penerbangan Domestik Gia Di Denpasar. Ekuitas: Jurnal Ekonomi dan Keuangan. Vol 15, No 3, pp: 370-395 
Rangkuti, Freddy. 2004. The Power Of Brands : Teknik Mengelola Brand Equity dan Strategi Pengembangan Merek Analisis Kasus dengan SPSS. Jakarta: PT. Gramedia Pustaka Utama.

Robbins, S. P. dan Judge, T.A. 2007. Organizational Behavior. New York: Prentice-Hall Jersey.

Ruiz-Martin, D. \& Rondán-Cataluña, F. J. (2008). The nature and consequences of price unfair- ness in services: A comparison to tangible goods. International Journal of Service Industry Management, Vol. 19, No. 3, pp: 325-352.

Shahroudi, K., Naimi, Seyedah S. 2014.The Impact of Brand Image on Customer Satisfaction and Loyalty Intention (Case Study: Consumer OF hygiene Products). International Journal of Engineering Innovation E Research, Vol. 3, No. 1, pp: 57-62.

Solimun. 2010. Analisis Multivariat Pemodelan Struktural Metode Partial Least Square- PLS. CV. Citra. Malang.

Subroto, B. Rahayu, A. 2014. Research on Impact of Customer's Satisfaction, Trust, Switching, barriets, and Corporate Image towards Customer's Loyalty (Cade Study: Telkom Flexi). International Journal of Science and Technology, Vol. 3, No. 11, pp: 704-710

Swasta, B. dan Handoko, H. 2010. Manajemen Pemasaran: Analisa dan Perilaku Konsumen. BPFE. Yogyakarta.

Tjiptono, F., \& Chandra, G. 2008. Pemasaran Strategik. ANDI Offset. Yogyakarta.

Virvilaite, R., Saladiene, V., dan Skindaras, D. 2009. The Relationship Between Price and Loyalty in Services Industry. Inzinerine Ekonomika-Engineering Economics, Vol. 3, pp: 96-104.

Widiyanto, Toro, J. S. 2012. Analysis OF influence of Service Quality and Price on Fairness with Customer Satisfaction customer Loyalty, Corporate Image and Variable Trust as Mediation: Studies in Customer PO. Rosalia Indah Surakarta. Fokus Manajerial, Vol. 11, No. 2, pp: 195-212.

Wirasti, Dian Retno. 2010. Pengaruh persepsi kualitas pelayanan, persepsi kewajaran harga dan corporate image terhadap loyalitas dengan kepuasan sebagai variabel mediasi pada layanan after-sales (service -part) toyota nasmoco solobaru. Masters thesis, Universitas Sebelas Maret.

Yee, Y. dan Faziharudean, T. M. 2010. Factors Affecting Costumer Loyalty of Using Internet Banking. Journal Of Electronic Banking System Faculty of Business and Accountancy. Vol. 1, No.1, pp: 1-21.

Yulihasri., Islam, Md Aminul., dan Ku Daud, Ku Amir. 2011. Factors That Influence Customer's Buying Intention On Shopping Online. International Journal Of Marketing Studies. Vol. 3 (1): 128-139. 